\title{
Access to Credit and Women Entrepreneurs: A Systematic Literature Review
}

\author{
Ferdinando Giglio ${ }^{1}$ \\ ${ }^{1}$ Department of Economics, University of Campania, Luigi Vanvitelli, Capua, Italy \\ Correspondence: Ferdinando Giglio, PhD, University of Campania, Luigi Vanvitelli, Corso Gran Priorato di Malta, \\ 1, Capua, 81043, Caserta, Italy. E-mail: ferdinando.giglio@ unicampania.it
}

Received: July 25, 2021

doi:10.5539/ijef.v13n10p12
Accepted: August 26, 2021

Online Published: August 30, 2021

URL: https://doi.org/10.5539/ijef.v13n10p12

\begin{abstract}
This document aims to investigate some of the problems faced by women entrepreneurs when they request access to credit.

Through the systematic review of the literature, documents relating to the research topic have been detected.

A detailed analysis revealed four main research areas: supply and demand barriers, obstacles related to the characteristics of the entrepreneur and the enterprise, lack of financial resources and problems related to the country's social and cultural traditions.

The different studies have been conducted in non-European countries. Studies could be carried in Italy given the shortage. Other variables may be added to the model.

It is a document that seeks to understand the situation in which women entrepreneurs find themselves, especially in the workplace.
\end{abstract}

Keywords: access, credit, gender problem, women entrepreneurs

\section{Introduction}

In many economies, women entrepreneurs continue to be in a position underlying men and are constantly struggling with gender issues (Nichter \& Goldmark, 2009).

But the problem they still face today is access to credit.

Women entrepreneurs, when they request access to credit, encounter various obstacles due to: problems on the demand and supply side; problems related to socio-cultural traditions; barriers related to the characteristics of the company that they manage and hitches on finding financial sources.

Regarding the first problem - obstacles on the demand and supply side - on the demand side, there is a greater aversion to risk (Croson \& Gneezy, 2009) and a possible lower propensity to negotiation by women than men (Badcock \& Laschever, 2003). Marlow and Carter (2006) find that women tend to ask for less funding because, on the one hand, they prefer to run smaller businesses and, on the other hand, are more reluctant to take on a debt burden (Carter \& Shaw, 2006 ). As for the offer, Muravyev et al. (2009) provide evidence of higher prices and less likely to obtain a loan when the entrepreneur is a woman. Alesina et al. (2012) find that women entrepreneurs pay higher interest rates without any evidence of greater risk.

As regards the second problem - social and cultural barriers -, traditional legal systems have denied women access to resources that lead to economic development: cultural values and beliefs play a fundamental role in shaping the country's institutions (Santos et al., 2016). Discrimination against women is pronounced when traditional roles are imposed by society, religion and cultural norms (Brush et al., 2014).

Regarding the third problem - obstacles related to the characteristics of the company -, the literature shows that there are differences between male and female owned companies for a series of attributes, such as: size of the company, level of education and experience of the owners (Brush, 1992).

Female-owned businesses tend to be organized as properties and not as companies (Cole \& Mehran, 2003). For this reason, they are smaller than their counterparts (Ciampi et al., 2018). Furthermore, the level of education of women entrepreneurs also differs from that of men (Van Uxem \& Bais, 1996; Moss \& Sounders, 1987). 
Male entrepreneurs have completed a technical school, while the education of female entrepreneurs is more economic and commercial in nature.

Instead, as far as experience is concerned, women are brought in for certain activities such as teaching, sales and administration (Hisrich \& Brush, 1993; Scott, 1986; Neider, 1987; Welsch \& Young, 1982) while men are more inclined to activities such as human resource management and financial management (Fischer et al., 1993; Van Uxem \& Bais, 1996) and therefore have more experience in running a business.

Finally, as regards the fourth obstacle - resorted to financial sources -, women's enterprises, having to face higher interest rates than their counterparts, therefore suffer discrimination from banks and must change the way in which they seek funds (Cavalluzzo et al., 2002).

For Kan and Storey (2003), Marlow and Carter (2006) and Irwin and Scott (2008), women are discouraged from seeking capital and rely on personal possessions or those of friends and relatives.

The work is divided as follows: in the second part, in addition to providing information about entrepreneurship, there will be a background on the problems faced by women entrepreneurs. In the third part, a vast literature on the main problems mentioned above will be presented; in the fourth part the methodology used will be explained; in the fifth part the main results obtained from different studies will be reported and, finally, in the sixth and last part, there will be the conclusions and implications for future research.

\section{Theoretical Background}

Entrepreneurship is recognized as the engine of growth in world economies. Scholars have proposed a wide range of definitions that have generated a number of different measures (Hebert \& Link, 1989).

A constant in the nature of entrepreneurship research has been the fluidity of the boundaries of domination. entrepreneurship embraced economics (Casson, 1982), sociology (Thornton, 1999), anthropology (Dana, 1995), psychology (Corsrud \& Krueger, 1995), political science (Homer-Dixon, 1995) and arts (Hoving, 1993).

Among the definitions, mention should be made of Gartner (1988): "Entrepreneurship is the creation of new organizations". According to this definition, entrepreneurship is considered in the perspective of four variables: individuals, i.e. the people involved in starting new organizations; the processes, or the actions taken to start a business; organizations, i.e. the type of business that is started and the environment that surrounds and influences the new business.

Instead, according to the definition of Venkataraman (1997), entrepreneurship is seen as "an academic field that seeks to understand how opportunities to implement future goods and services are discovered, created and exploited, by whom and with what consequences". Venkataraman's discussion of this definition of domination focuses on two main concepts: how individuals recognize opportunity and how they take advantage of it (Shane \& Venkataraman, 2000).

Herbert and Link (1989) identified three distinct intellectual traditions in the development of entrepreneurial literature. These traditions are characterized by: the German tradition based on von Thuenen and Schumpeter, the Chicago tradition based on Kinght and Schultz and the Austrian tradition based on von Mises, Kirzner and Shackle.

Among these, the Schumpeterian one had the greatest impact on contemporary entrepreneurial literature. The distinctive feature of Schumpeter is that entrepreneurship is seen as an unbalancing phenomenon rather than a balancing force. In his classic 1911 treatise, "Theory of Economic Development", Schumpeter proposed a theory of creative destruction, in which new businesses with an entrepreneurial spirit replace less innovative operators, leading to a higher degree of economic growth. Even in the 1942 classic, "Capitalism and Democracy", Schumpeter argued that large entrenched companies tended to resist change, forcing entrepreneurs to start new businesses in order to pursue innovative businesses.

When it comes to entrepreneurship, this concept is linked to that of an entrepreneur. Numerous authors underline the fact that entrepreneurship and entrepreneurship are male concepts. It could be argued that this is due to the fact that entrepreneurs have traditionally been men: several studies claim that female entrepreneurs have been made invisible, both in research and in the media (Baker, Aldrich, \& Liou, 1997; Sundin, 1988). Other authors discuss male measuring instruments (Moore, 1990; Stevenson, 1990), gender attitudes towards entrepreneurs (Nilsson, 1997) or male gender theory (Bird \& Brush, 2002; Chell, Haworth, \& Brearley, 1991; Mirchandani, 1999; Reed, 1996).

In literature the first definitions of entrepreneur can be counted in Hagen (1962), Knight (1921) McClelland (1961) and Schumpeter (1934) describing him as an individual with an unparalleled desire for success; risk-tolerant, 
tolerant to ambiguity; independent, tenacious and a good motivator (Alpkan, Bulut, Gunday, Ulusay, \& Kilic, 2010; Bourne, 2011; Comeche \& Loras, 2010; Ga'mez-Gonza'lez, Rondan-Catalun, Diez-de Castro \& Navarro-Garci'a, 2010; Harmiga, Batista-Canino, \& Sa'nchez-Medina, 2011; Koutonen \& Palmroos, 2010; Lin, 2010; Mainardes, Alves, \& Raposo, 2011; Sebora \& Theerapatvong, 2010; Wakkee, Elfring, \& Monaghan, 2010 ).

Schumpeter (1934) saw entrepreneurs as the driving force of the economy by highlighting their innovative nature that triggers the famous creative destruction (Ca'ceres, Guzma'n, \& Rekowski, 2011; Cavalcante, Kesting, \& Ulhoi, 2011; Goktan \& Miles, 2011; Hotho \& Champion, 2011; Huang, Chau, \& Lee, 2010; Huarng \& Yu, 2011; Naranjo- Valencia, Jime'nez-Jime'nez \& Sanz-Valle, 2011; Zhang \& Duan, 2010).

More recently, other authors (Brush et al., 2003; Busenitz et al., 2003; Gartner, 1990) examine entrepreneurs in terms of activities, i.e. from the point of view of creating new businesses. A more general description, however, sees the entrepreneur as an individual who participates in the company's decision-making processes (Di'azGarci'a \& Jime'nez-Moreno, 2010; Morales- Gualdro'n, Gutie'rrez- Gracia, \& Dabo'n, 2009; Pardell-Val, 2010; Peris-Ortiz, 2009; Petkova, 2009; Pyromalis \& Vozikis, 2009; Safo'n, 2009; Sanfield \& Lussier, 2009; Sebora \& Theerapatvong, 2010; Tihula \& Huovinen, 2010; Talstoy, 2010). But despite this, the concept of female entrepreneurship is also gaining in value and the number of female entrepreneurs continues to increase steadily.

\subsection{Success of Women Entrepreneurs}

Women's enterprises are one of the fastest growing entrepreneurial populations in the world. They offer a significant contribution to innovation, employment and wealth creation in all economies (Brush et al., 2006).

According to Lavoi (1985), a female entrepreneur is the "female manager of a company that takes the initiative to start a new one, accepting the associated risks, financial, administrative and social responsibilities and actually managing the company's daily activities".

Several studies (Reynolds, Hay, \& Camp, 2000) declare that long-term growth and ownership require the participation of women in businesses, the potential of which requires an analysis of the differences from men in terms of how they act and think.

Ali (2013) reports that women produce over 80\% of the food for sub-Saharan Africa, 50-60\% for Asia, 26\% for the Caribbean, 34\% for North Africa and Middle East and over 30\% for Latin America. In Nigeria, scholars have reacted to the role of micro-small and medium-sized enterprises and considered them to be the main drivers driving national economic growth. The involvement of women in these companies contributes over $97 \%$ to entrepreneurship, 60\% of the national GDP and 94\% of the total employment share (Mayoux, 2001; Udechukwu, 2003; Ndubulze, 2004). Women entrepreneurs contribute to high economic growth since Nigerian women own around 25-30\% of the registered companies (Iyiola \& Azuh, 2014).

What may be considered the first written article on business creation by women was published in 1976 in the Journal of Contemporary Business, written by Eleanor Brantley Schwartz and titled "Entrepreneurship: a new female frontier". The author concluded that the main motivation for women to set up a business was the same as for men: need for success, independence, economic reward and job satisfaction. Like men, women create a business for a variety of reasons, which can be extrinsic, intrinsic or transcendental in nature.

According to a series of studies (Cromie, 1987; Gatewood, Shaver, \& Gartner, 1995; Goffee, Scase, \& Pollack, 1982; Ram, 1999; Heilman \& Chen, 2003; Hisriche \& Brush, 1986; Starger, 1990), the motivation of intrinsic and transcendental nature predominates among women, while men are driven to create businesses mainly for extrinsic reasons.

As for the intrinsic factors that influence the creation of new businesses, some authors note that women tend to be motivated by internal aspects such as the desire for independence (Carter \& Cannon, 1991; Gatewood et al., 1995; Hisrich \& Brush, 1986; Humphreys \& McClung, 1981; Stanger, 1990), the desire for self-fulfillment and internal control (Kalleberg \& Leicht, 1991; Mescon \& Stevens, 1982; Woddell, 1983), perseverance (Deng, Harsan, \& Jivan, 1995) and an interest in meeting the challenges posed by the creation of a new company, the opportunity to develop one's skills and experience and the possibility of influencing one's destinies.

The most important of the transcendental reasons why women set up new businesses seems to be the desire to have an adaptable job that allows them to combine their working life with the needs of their families (Goffee \& Scese, 1985; Scott, 1986). Watking (1983) identifies business creation as a strategy that offers solutions to women who leave the job market for family reasons. Studies that exclusively examine factors that influence women indicate that the balance between family and work life is the biggest obstacle for women in terms of starting a new business (Mroczkowski, 1997) although some studies actually cite this factor as reason to start creating a new one (Sulliva, Halbrendt, Wang, \& Scannell, 1997). 
Over the past two decades, academic literature has seen an increase in interest in female entrepreneurship in various countries around the world. As a result, female entrepreneurs now attract considerable attention as a full-fledged topic of academic debate (Carter et al., 2007). Welter (2006) notes that women in business are a growing force in the transition economy and environment and that their contribution extends from the economic sphere to include the wider process of social transformation. A Unido report on Africa also recognizes this trend as women have been held responsible for most of the activities in Africa (Unido, 2008).

This finding is also reflected in various studies indicating that women own and manage around a third of all businesses in the formal sector and represent the majority of businesses in the informal sector (Bardasi et al., 2007; World Bank, 2007; Aderemi et al., 2008).

The productive activity of women, especially in industry, gives them economic power and allows them to contribute more to the overall development. Regardless of whether they are involved in small and medium-scale activities in the informal or formal sector, women's entrepreneurial activities are not only a means of economic survival, but also have a positive social repercussion for women themselves and their environment (Unido, 2001).

Women's businesses are an increasingly important part of the United States economy in terms of the number of businesses owned, revenue and employment. In the late 1990s and early 2000s, the number and revenue grew by $17 \%$ and 39\% respectively. Both exceeded national averages (Gatewood et al., 2004). Also in Bangladesh women represent about half of the population and their contribution in the economic sectors has significantly improved in the last decades (Ahmed, 2014).

One of the main projects supporting women was the Diana Project International in collaboration with the Entrepreneurship and Small Business Research Institute. In 2003, the first international meeting of scholars met in Sweden to exchange ideas and learn from each other on the current state of research on the creation and support of new women-led businesses. Diana International was designed to provide a platform from which to develop, conduct and share a global research agenda and create an international community of scholars dedicated to answering questions about women entrepreneurs and growth-oriented businesses.

The product of Diana's first international conference was a report that discussed the importance of growth-oriented businesses led by women and which summarizes the state of knowledge of these companies in the countries initially involved. For the second conference in 2004, the participants presented working papers and, from this conference, the main documents were peer-reviewed, revised and finally examined for a volume by growth-oriented women and their activities. (Brush et al., 2006). Despite this, women entrepreneurs continue to find themselves in a position below men and for this reason they face various obstacles that do not allow them to grow.

\subsection{Obstacles Encountered by Women Entrepreneurs}

Despite these successes, the reality of the situation in many economies is very different: women entrepreneurs continue to find themselves in a position underlying men and constantly struggle for gender issues (Nichter \& Goldmark, 2009).

Gender is a social construction of sex in which characteristics are attributed to men and women based on the notions of femininity and masculinity (Oakley, 1973). Gender is articulated through a binary division that presents a series of stereotyped male and female behaviors in which the former is privileged over the latter.

As Crannie-Francis, Waring Stavropoulos, and Kirky (2003) note, "the male side is coded as the positive side and becomes the standard by which all the others are judged".

In Ancient Greece, Aristotle claimed that women were weak, cautious, domesticated and polite while men occupied the opposite position, making them superior (Tredennick, 1968). These representations still persist today. Lister (2003) in his analysis of gender and citizenship, describes man as a rational, impartial, independent, active and strong individual while women are presented as emotional, irrational, dependent, passive subjects and focused on domestic concerns. According to Elborgh-Woytek et al. (2013), if women could fully develop their potential in the labor market, the gross domestic product would increase and growth would be stimulated by mitigating the impact of the reduction of the workforce. However, women-led businesses still represent a small percentage of men-led businesses although less pronounced in low- and middle-income countries, where women's participation in entrepreneurial activities is greater, due to the difficulties encountered in accessing markets of work (Minniti et al., 2005).

This is confirmed through studies conducted in several developing countries and in particular in sub-Saharan Africa (Coleman, 2002; Olomi, 2001) and supported by different theories that have been advanced by different scholars and that perpetuate the ability of men to manage business with respect to women. Theories complete the 
bad idea that women are weak in business than men and therefore it is risky to trust them. Among the theories, this is supported by the Achievement Motivation Theory (Davidsson \& Wiklund, 1999; Olomi, 2001) which argues strongly against women and argues that men are more capable in conducting business because they are their role and are more effective in productive roles (Kessy, 2009). This theory is complemented by theories of human capital, social networks, organizational ecology that claim that women entrepreneurs are more inclined to invest their time in managing family relationships (Jacobsen, 1998; Brush, 1992; Morduch, 1999; Wiliamson, 1995; Tigges \& Green, 1994). Feminist theory also clearly underlines that women's affairs cannot be successful unless the systematic prejudices that hinder women's enterprises are removed or minimized (Ely \& Padavic, 2007; Nafziger, 1997).

In recent decades, the credit constraint has been identified as one of the main problems that inhibit the growth and sustainability of SMEs in emerging market countries, especially women-owned businesses (Improve access to finance for property of women in India, 2014). The conditions of access to a wide range of financial services and the level of related costs are fundamental for the survival and development of businesses. Indeed, SMEs rely heavily on bank credit as their main source of finance as they are unable to access equity markets (Caglayan \& Xu, 2016; Inkloor et al., 2015; Kremp \& Sevestre, 2013; Mor and Fink , 2013; Vermoesen et al., 2013).

Therefore, the issue of access to credit is considered crucial by policy makers and researchers (Berger \& Udell, 2006; Cole \& Sokolyk, 2016; Kirschenmann, 2016), given that SMEs dominate the business landscape in Europe and are the main engines of employment, growth and innovation (Degryse \& Van Cayseele, 2000; Dekok et al., 2011; Ferreira et al., 2016; Popov \& Udell, 2012).

\section{Literature Review: Obstacles on the Supply and Demand Side}

A significant body of literature underlines that difficulties in accessing bank credit may be greater for female-led enterprises, and this, in turn, affects their investment opportunities (World Bank, 2011). This branch of literature examines these problems on both the supply and the demand side.

From the demand side, several studies have shown that women entrepreneurs are more risk averse than their male counterparts (Halt \& Luary, 2002; Eckel \& Grossman, 2008; Neelakanton, 2010; Ivanova Yordanova \& Ivanova Alexandrova-Boshnakova, 2011); they also tend to refrain from applying for loans since their general inclination to be less secure could lead them to be more skeptical about their ability to obtain financing (Carter, Mwaura, Ram, Trehan, \& Jones, 2015; Chaudhuri, Sasidharan, \& Ray, 2018; Croson \& Gneezy, 2009; Malmstram, Johansson, \& Wincent, 2017; Ongena \& Popov, 2016; Poczter \& Shapsis, 2018; Raper \& Scott, 2009; Treichel-Zimnerman \& Scott, 2006). In financial markets, differences in preferences and risk attitude can lead to differences in the approach to requesting external financing between male and female companies. As for the United States, Cavalluzzo et al. (2002) find some significant evidence that female businesses are more likely to avoid applying credit because they anticipate a denial as the credit market becomes more concentrated. Some authors believe that women show different demand patterns even when their applications do not show a significantly higher probability of being rejected (Coleman, 2000; Cole \& Mehran, 2009). Robb and Walken (2002) find that women are more likely to borrow credit cards because they fear rejection for credit history reasons. Marlow and Carter (2006) find that women tend to ask for less funding because, on the one hand, they prefer to run smaller businesses and, on the other hand, are more reluctant to take on a debt burden (Carter \& Shaw, 2006 ).

For these reasons, women's enterprises act as discouraged debtors (Freel et al., 2012; Kolnins \& Williams, 2014; Kon \& Storey, 2003; Moro et al., 2017).

As regards the issue of gender discrimination on the supply side, the literature identifies two different types of discrimination: one based on taste or prejudicial - guided by preferences and beliefs that are not based on objective criteria - and the statistical one - which occurs when collecting information on the company's solvency is difficult and expensive -.

In these situations, the necessary information is provided so easily by observing obvious characteristics, such as the genus (Aristei \& Gallo, 2016; Bellucci et al., 2010; Mascia \& Rossi, 2017). Several studies suggest that credit requirements imposed by banks are more likely to favor male rather than female businesses, this is because lenders have different perceptions of entrepreneurs' potential (Alsos \& Ljunggren, 2017; Carter et al., 2007; Marlow \& Patton, 2005).

Women's enterprises can face: a higher rate of refusal of their loan applications (Cavalluzzo et al., 2002); a partial refusal by the funder (Kremel \& Yazdanfer, 2015; Treichel-Zimnerman \& Scott, 2006); and higher price conditions or the obligation to provide higher guarantees for the credit provided (Alesina et al., 2013; Bellucci et al., 2010; Mascia \& Rossi, 2017; Muravyev et al., 2009; Wu \& Chua, 2012). 
The use of survey data for the United States National Survey of Small Business Finance finds evidence of price discrimination (Cavalluzzo et al., 2002). Turning to tests outside the United States, Madill et al., (2006) discover that Canadian firms do not show different application rates or bank rejection rates than men, but their relationships with banks are shorter. Using company survey data (BEEPS), for a number of countries, including economies from the east and some western European countries, Muravyev et al. (2009) provide evidence of higher prices and less likely to get a loan when the entrepreneur is a woman.

As for Italy, using bank data, Alesina et al. (2012) find that women entrepreneurs pay higher interest rates.

\subsection{Social and Cultural Barriers}

In many countries, traditional legal systems and discriminatory approaches have denied women access to resources that lead to economic development. Cultural values and beliefs play a vital role in shaping the country's institutions (Santos et al., 2016). Discrimination against women is pronounced when traditional gender roles are imposed by society, religion and cultural norms (Brush et al., 2014). Tambunan (2009) discovers that Indonesian women entrepreneurs face serious legal restrictions and unequal inheritance rights. Martson (2014) notes that women are unable to register an activity in the Democratic Republic of the Congo and Pakistan. Brush et al. (2014) found that the cultural environment influenced business motivation and perception. Furthermore, De Vita et al. (2014) and Kelly et al. (2014) have shown that, in Arab societies, cultural traditions inhibit women's entrepreneurial initiatives. Brush et al. (2014) and Welter and Smallbone (2008) have shown that in the Uzbekistan region in the Ferghana valley, men prevent the choice of women's activities and keep them at home as prescribed by Shariah. In Moldova, most women need to obtain family consent to engage in commercial activities (Welter et al., 2003). In Tajikistan, the company taught women who were unable to manage business (Culture, 2010). In traditional Islamic societies, women must abide by social norms such as purdah and izzat, which further limit women's opportunities for self-employment (Roomi \& Parrott, 2008; Roomi \& Harrison, 2010; Roomi, 2011). Purdah literally means "veil" and refers to a system of isolation between men and women. Isolation is supported by both spatial and symbolic barriers. Women should act modestly and remain within the domestic spheres with men working outside the home (Roomi \& Harrison, 2010). Many Muslim women wear burqua which covers the whole body including the face and which has been described as a portable means of isolation (Papanek, 1982). Izzat means "honor" and refers to the rule that women are custodians of the honor of their families. This puts enormous pressure on girls and women to maintain a good reputation (Roomi \& Parrott, 2008).

This is because in traditional Islamic contexts, it is not socially accepted that women run their own business or even work outside the home: the fear is that a married woman who starts making her money may change traditional family roles and undermine domestic relations. patriarchal. When a married woman works for money outside the home, it is interpreted as the result of her husband's inability to "control" his wife or his inability to provide for his family (Amine \& Staub, 2009).

So in many countries there are cultural barriers that don't allow women to participate fully in business. Even in countries that support women, this support is often not applied significantly. This is the case in Bangladesh. Harrison and Mason (2007) argued that family responsibilities and lack of entrepreneurial experience could hinder women as entrepreneurs. Ahmed (2014) and Brush et al. (2014) have suggested that women are often excluded from many profitable corporate networks due to the overload of domestic responsibilities.

\subsection{Obstacles Related to the Characteristics of the Company}

The vast literature on gender and entrepreneurship also shows that there are differences between male and female owned businesses for a number of attributes (Ahl, 2006; Brindley, 2005). Brush (1992) argued that the differences in male and female psychology concern the size of the company, the level of education and experience of the owners who manage it and the age.

The expansion of the company is an influential factor in female entrepreneurship. Several authors agree that most women start small businesses, both in terms of turnover and number of employees (Carter \& Rosa, 1998; Cowling \& Taylor, 2001; Cuba et al., 1983; ENSR, 1996; Hisrich \& Brush, 1983; Humphreys \& McClung, 1981; Scott, 1986).

As a result, the size of the company, which is often used as a basis for evaluating performance, leads to the idea that small businesses created by women represent a weakness in their ability as business owners.

The causes commonly cited for the creation of smaller businesses by women are, on the one hand, the greatest difficulties they encounter in finding resources to finance their projects and, on the other, the lack of specific knowledge to carry out successfully the tasks involved in running a business. Evidently, both reasons are related to discrimination against women in the labor market. 
Female-owned enterprises are concentrated disproportionately in crowded subsections of lower-order services and are relatively scarce in value-added / production / innovation services (Marlow, Carter, \& Shaw, 2008; Hart et al., 2011; Duberley \& Carrigen, 2012). In general, women's enterprises tend to be organized as property and not as a company (Cole \& Mehran, 2003).

Some studies (Ciampi et al., 2018; Riding \& Swift, 1990; Stefani \& Vacca, 2013) have found that young and small businesses tend to be characterized by lower sales growth. In terms of sector concentration, companies that are in some sectors, such as in the services and retail sector, have an underperformance compared to their counterparts that are in higher capital sectors (Bloice \& Burnett, 2016; Bonfenti et al., 2018; Bresciani et al., 2017; Carter et al., 2001; Del Giudice et al., 2018; Cavaliere et al., 2015; Papa et al., 2018b).

Furthermore, the lack of opportunities to develop managerial and technical skills, lack of education and business experience also limit women's business performance (Chowdhury, 2006; Chowdhury et al., 2010; Ahmed, 2014).

The level of education of women and male entrepreneurs is approximately identical, while the type of education differs (Van Uxem \& Bais, 1996; Moss \& Saunders, 1987).

Male entrepreneurs are more likely to have completed a technical school, while entrepreneurship education is usually more economic, administrative or commercial in nature. Furthermore, women entrepreneurs are more specialized in personal services (Van Uxem \& Bais, 1996). The length and type of experience of women and men in the labor market vary considerably. Men are more likely to have been employed before starting their business and tend to have more work experience (Van Uxem \& Bais, 1996; Welsch \& Young, 1982).

Differences in the type of experience are related to differences in the type of education. Women entrepreneurs are more likely to have experience in fields such as teaching, sales, administration and personal services (Hisrich \& Brush, 1983; Scott, 1986; Neider, 1987; Welsch \& Young, 1982) than management, science and technology (Watking, 1983; Stevenson, 1986). Men have more experience in the field of human resource management, financial management and the application of modern technologies (Fischer et al., 1993; Van Uxem \& Bais, 1996). In addition, entrepreneurs work more often full time than their female counterparts (OECD, 1998). Over half of the enterprising women carry out other activities in addition to running their own business, such as being employed or taking care of their family which leads them to have little experience in the subject (Stigter, 1999).

The MIDES-SMEF study also observed that few women in Bangladesh had high levels of education regarding management skills. A small number of women were focused on export - import activities, but the vast majority of them were involved in local markets. The study also indicated that most of the respondents entered entrepreneurship with fewer years of experience (Ahl, 2004; Coleman, 2007; Kabeer, 2012). In Bangladesh, however, about $70 \%$ of women entrepreneurs were self-taught compared to $44 \%$ of men (IFC, 2011). In 2010, a report by the Minister of Industry mentioned that the lower educational outcomes of women in Bangladesh are largely responsible for their inadequate performance in SMEs (Chowdhuri et al., 2010).

Age also affects the probability of being financed. In other words, banks' perception of age affects access to bank loans because old entrepreneurs are generally considered non-innovative and more reliable (Fang \& Nafsinger, 2009). On the contrary, young entrepreneurs are perceived as more innovative and, since there is no risk-free innovation (Merton, 2013), they are considered more risky from the bank's point of view. Consistent with other studies (Nguyen \& Luu, 2013; Ogubazghi \& Muturiwe, 2014) young entrepreneurs face narrower obstacles in accessing credit banks than older ones.

For these reasons, women are discriminated against by banks (Angori, Aristei, \& Gallo, 2017; Coleman \& Cursky, 1996; Coleman \& Cursky, 1990; Coleman \& Robb, 2009; Fabowale \& Mascia, 2018; Orser \& Riding, 1995) which do not grant due loans.

\subsection{The Use of Personal Resources}

Some theories of discrimination underline the tendency of banks to internalize the social hierarchies existing in society (Shulman, 1996). Such a theory known as organizational adaptation explains the tendency of businesses and other organizations to adapt to social conventions in the external environment (Shulman, 1996). In the context of the credit markets, lenders may internalize society's norms and beliefs that favor men over women and, therefore, are less willing to lend to women. Weiler and Bernasek (2001) develop a theoretical model to explore the idea that women entrepreneurs cannot perform as their male counterparts because of their exclusion from networks with suppliers, workers, customers and neighbors. Lenders, if they are aware of it, may themselves be less inclined to lend. All of these discrimination theories raise the possibility that differences in credit rationing by gender may reflect discrimination by banks. Some studies explore the relationship between capital rationing and discrimination (Blanchflower et al., 2003). If capital is rationed more for women than for men, it has been argued that capital 
rationing is a form of discrimination. Existing literature addressing gender discrimination in small business credit markets has produced mixed results. Although some argue that there is no discrimination against women owners in accessing credit (Blanchflower et al., 2003; Mitchell \& Pearce, 2005, Robb et al., 2002), others find evidence that owned businesses women have to face higher loan negotiation ties (Cavalluzzo et al., 2002), concluding that women face discrimination by banks.

Therefore, women tend to change the way they look for funds. For Kan and Storey (2003), Marlow and Carter (2006), Irwin and Scott (2008), women are discouraged from seeking capital and rely on personal possessions or those of friends and relatives. Research conducted by the IFC in the Middle East and North African countries (Mena) indicates that women entrepreneurs at the SME level finance their businesses and expansions from personal sources (Roomi, 2005). Most of the 256 respondents in the Roomi 2005 study had to tap into personal savings to finance their business. This trend was also evident in the ILO survey, which noted that $73 \%$ of women used their private savings as initial seed capital, with only 4\% accessing formal credit sources (Goheer, 2003).

They also use internal sources to start their own business. A high percentage of entrepreneurs start their own business with their own savings or with the support of friends and family (Rutashobya \& Nchimbi, 1999; Woldie \& Adersua, 2004; Rutashobya et al., 2009). The availability of adequate financing for fixed assets and working capital is a serious problem for women entrepreneurs in Africa, despite the various sources from which SMEs can access credit (Brush et al., 2001-2002; DTI, 2005). Various studies show that women entrepreneurs typically obtain their initial investments and working capital from internal sources, i.e. their savings, profits and loans withheld by friends (Brush, 1990). This is sometimes complemented by short-term credits offered by suppliers and advances from buyers. It is also noted that they use traditional banking sources to satisfy their capital requirements (Anna et al., 1999; DTI, 2005). Previous research has revealed that this may be due to the fact that the female entrepreneur is very young compared to her male counterpart; they are unprecedented and inexperienced.

Davidsson and Honig (2003) point out that the support offered by family members provides an important form of social capital. The perception of family social support by Indian women entrepreneurs can also serve as an important resource for achieving growth. This derives from the point of view that high levels of support can promote entrepreneurial persistence and risk-taking (Bruderl \& Preisenderfer, 1998).

Important in this context is the prospect of the "incorporation of the family" (Aldrich \& Cliff, 2003), following the work of Welsh et al. (2014), due to the prevalent involvement of the family in new initiatives through ownership and / o managing or providing support to businesswomen (Chang et al., 2009; Welsh et al., 2014). As part of the vision of family incorporation, Chang et al. (2009) examine how family support influences the creation of businesses between Hispanic entrepreneurs in New England in the United States (Aldrich \& Cliff, 2003).

The authors believe that family support, in the form of resources and encouragement, has a positive impact on starting businesses.

A recent study by Chang et al. (2012) on Korean entrepreneurs, suggests that family involvement can provide support in terms of resources, encouragement, norms, values and social capital, as well as networks for the creation and success of companies (Aldrich \& Cliff, 2003; Chang et al., 2009-2012; Pearson et al., 2008). As a result, past research has also drawn attention to the positive influence of family members in the strategic management process. Family members tend to exhibit altruistic and educational behaviors, such as mentoring and orientation that can positively contribute to starting activities and success in managing new initiatives (Steir, 2003; Arregle et al., 2007). In addition, family members can provide entrepreneurs with the use of family finances or help them obtain external sources of funding (Aldrich \& Cliff, 2003; Anderson et al., 2005; Dyer \& Handler, 1994). In fact, family members represent important resources for businesswomen in particular for those who may not have access to other networks during the business development process (Greve \& Salaf, 2003).

Furthermore, many women come from low-paid employment and unemployment, and as such they lack savings or guarantees for external funding (Riding \& Swift, 1990; Brush, 1990; Carter \& Rosa, 1998; Fielden et al., 2003; Fuller-Love, 2008).

\section{Material and Method}

In my research I used a systematic review of the literature whose goal is defined as "integrating a series of different works on the same topic, identifying common elements, contrasting differences and extending the work" (Meredith, 1993). Systematic literature review is an appropriate method for identifying, selecting and analyzing existing literature on a given topic (Denyer \& Tranfield, 2009).

I include articles and some book chapters while non-referenced articles are excluded (Light \& Pillemer, 1984; Ordanini et al., 2008). 
The purpose of this research is to extend knowledge on the issue of women entrepreneurs and, in particular, the problem of access to credit. To locate the documents, I used the Scopus database. In addition, to delimit the number of documents, I have selected the period 2000-2020.

The analysis of the literature took place through three steps listed below:

1). Research;

2). Elimination of texts not suitable for the research topic and addition of new ones;

3). Further skimming and evaluation of the full text.

Initially I entered the following words: access to credit * and women entrepreneurs *.

The database found 7790 articles on access to credit and 2917 on women entrepreneurs. To restrict the number of documents, I combined the words and got 78 results.

Reading the abstracts, not all the documents were suitable for my research theme, so from 78 we went to 47 . To find other documents that dealt with my theme, I clicked the item "related documents" under the papers that interested me and I have found 242 documents.

Of these 242 articles, I made a further creaming after reading them entirely and, finally, I selected 102 articles.

Table 1 describes the steps taken to complete the systematic literature.

Table 1. Systematic literature review procedure

\begin{tabular}{lll}
\hline Filter & Description & $\begin{array}{l}\text { Database: Scopus } \\
\text { Number of documents }\end{array}$ \\
\hline Step 1 & Selected articles with keywords: & 7790 \\
& access to credit * & 2917 \\
& women entrepreneurs * & 78 \\
\hline & Articles selected after merging keywords & 47 \\
& Articles selected after reading the abstracts & 242 \\
\hline Step 2 & Articles selected after adding others via the "related documents" item & 102 \\
\hline
\end{tabular}

\section{Empirical Results}

The study conducted in Italy, particularly in southern Italy, is represented by a sample of 428 companies randomly extracted from Aida. The independent variables chosen are: gender (female), age, education and experience while those dependent on loan application and approval. The results show that only age appears to be a significant predictive factor for both the application and the approval of the loan. Older applicants are more likely to apply for loans than young entrepreneurs and get their application approved.

The study found no evidence that education and experience did not affect the probability of borrowing or the repayment probability.

Another study carried out in Italy - making a comparison between north and south - is represented by a sample of 219 companies extracted from Aida. The dependent variables are: the ROE and the price of credit while the independent ones are: female manager, board of directors, organizational model, position, size and industry. The results showed that the presence of women on the CDA positively influences ROE. The companies located in southern Italy are less performing than the rest of the country. The presence of a woman as a manager has a positive impact on the price of credit. Cooperative companies pay higher interest rates because the banking system is exposed to greater risk in the event of insolvency.

Another study also conducted in southern Italy is represented by 214 SMEs randomly extracted from Aida. The dependent variable is: bank loan of a company while the independent ones are: gender, age, education and ethnicity. The results of this study have shown that the loans of male entrepreneurs are accepted more than those of women; older and better educated entrepreneurs are given more loans and finally white entrepreneurs are treated better than black entrepreneurs.

The U.S. study used the Kauffman Firm Survey. The dependent variables used are: register of total financial investments and total equity investments.

The independent variables are: characteristics of the company (size) and of the owner (education and experience). 
The results revealed that men are more educated and have more years of work experience. Instead, women started the business with less capital because they are more adverse and manage smaller companies.

Another study in the United States, especially Illinois, a random sample of 1498 companies was selected from the lists of Harris Illinois services and manufacturers.

The dependent variable used is the use of bootstrap financing while the independent variables were the education, the age of the owner, the agreements made for external capital, the gender and the change in sales compared to the previous year. The results of this study showed that although bootstrapping is convenient, women have used it less and less than their counterparts.

The study carried out in Jamaica is based on data from a survey conducted on 247 small businesses in the Jamaican economy. Since there is no sample for small businesses in Jamaica, snowballing has been used. The collection phase began with information that researchers have been able to ascertain about businesses from institutions such as the Small Business Association of Jamaica, banks, private sector bodies and other business organizations.

The dependent variables are: gender and credit behavior while the independent ones: characteristics of the owner (education and years of work experience); company characteristics (dimensions based on the number of employees, age relative to the number of years of activity and organizational form measured by the company's legal structure). The results of this study showed that men have higher education levels than women and more years of work experience. Male-owned companies are organized as companies unlike female-owned ones. Male entrepreneurs work in companies born in more remote times. Finally, the study argued that women are more risk averse than their male counterparts.

The study conducted in South Africa, particularly in the regions of East London, Port Elizabeth, Queenstown and King Williams Town, used data collected through a survey using a self-administered questionnaire which includes both closed-ended and Likert-scale questions. The dependent variables used are: credit demand and availability of credit while the independent ones: characteristics of the company (number of employees, possession of guarantees and company sector) and characteristics of the entrepreneur (membership of associations, education at degree level and age ).

Regarding the demand for credit, the study revealed that women apply for fewer loans than men while there were no differences in the availability of debt for men and women.

The study, however, conducted in Australia and in particular in Western Austria, New South Wales, Victoria, South Australia and Tasmania was done through surveys.

The dependent variables are: growth and finance. The independent variables are: company size, age, sector, education, experience, reimbursement and demand. The study revealed that women run smaller companies than men, they are much younger and less educated than their male counterparts. They also work in areas such as retail, commerce and consumption and have less working experience (less than 10 years).

Finally, as regards repayment and demand, it has been observed that women are less likely to have repaid their debt late and to have asked for funding.

The study conducted in South Asia in the cities of Bangladesh, Bhutan, India, Nepal and Pakistan, used the data collected by the World Bank Enterprise Surveys.

The dependent variable is: credit constraints. The independent variables are: gender and woman in parliament. The results showed that the woman in parliament is negatively related to credit constraints.

The study carried out in Eastern Europe and Central Asia is based on data from the 2005 Business Environment and Enterprise Performance Survey.

The survey covers 34 countries and provides information on 14108 companies, $300-600$ per country.

The dependent variables are: gender and access to bank financing. The independent variables are: age, number of employees, level of capacity utilization and percentage of sales. The results of this study showed that women pay higher interest rates and therefore are less than 5\% more likely to receive loans.

The study conducted in Nigeria, in the city of Awka, used questionnaires. The dependent variable used is: entrepreneurial development while the independent variables are: source of initial capital, source of the interviewee's loan, number of loans, situations in which the interviewee has requested loans, the need for guarantees and the situation in which credits / loans had repayment terms. The results showed that women lack funding because of the financial institutions' inaccessibility to credit. They rely more on the funds of friends and relatives to start the business. 
Another study also conducted in Nigeria, in the city of Lagos, used a questionnaire.

The dependent variable is access to credit while the independent ones are gender, age, educational level, sector and experience. It has been observed that women face difficulties in accessing credit because they have less work experience and less education than men. In addition, they are engaged in low-income sectors.

In Sudan, in Khartoum State, questionnaires were used as primary data while books and reports were used as secondary data.

The dependent variable used is gender while the independent ones are: complexity of administrative procedures, lack of project marketing, lower profit margin, role of the financial company, lack of awareness of investments, guarantees, work experience, payment period and problems in the 'obtain financing. The results of this study revealed that all these features contribute to hindering access to credit for women entrepreneurs.

In a study conducted in the Great Lakes and Plains Region, data from the Credit, Banks and Small Business survey conducted by the National Federation of Independent Business were used. The dependent variable used in this study is the loan application from a bank while the independent variables are: gender, size of the business, years of activity, sales growth, shape of the business and the sector. The results of this study revealed that female entrepreneurs do not apply for a loan from a bank because of the variables mentioned above. Women recorded a smaller loan size and a difference in attitudes towards external financing was also noted.

In Finland, the Netherlands, Italy, Austria, Spain, France and Germany a SAB survey was conducted by the ECB.

The dependent variables are: requesting external funds and obtaining external funds. The independent variables are: gender, age, sector, country, ownership, market share, concentration of the banking system, size, share capital and bad debt.

The results of this study have confirmed that women entrepreneurs do not require external sources and in fact rely on the sources of relatives and friends. Furthermore, they do not obtain external sources because they are considered adverse.

The study conducted in China used data from the Chinese Securities Market and Accounting Research organization. The variable employee is the cost of debt. The independent variables used concerned the structure of the board (size, independence and board activity), ownership (institutional participation, state-owned enterprises and share owned by the members) and economic conditions (risk, growth, opportunity, short-term debt ratio and in the long term, market performance and ROE). The results showed that women are less risky and are less accused of debt financing. In addition, it has been reported that they are more concerned with the status of their family.

In Peru, in the city of Lima, a sample of notary loans was used. The dependent variable is the gender and the loan request. Independent variables are. Experience, marital status, education, maturity and reimbursement. The results showed that women entrepreneurs, especially when they are married and have children, are rarely granted their loan applications. This is because they have fewer years of experience and a lower level of education than their male counterparts.

In another study also conducted in Peru, the data were taken from loan recordings of borrowers and from interviews in three branches: Comas, San Juan de Miraflores and Chimbote.

In this study, the dependent variable is the time of acceptance of the loan while the independent variables are the guarantees and documents required sector. The results of this study showed that the waiting period between the application and the delivery is about two months. In addition, women are charged a lower interest rate than the commercial one. Women apply for small loans because they are engaged in areas such as commerce and services. They have no information on credit programs.

The main results are shown in table 2 . 
Table 2. Empirical results

\begin{tabular}{|c|c|c|c|c|}
\hline Studies & Place & Indipendent variables & Dependent variables & Main findings \\
\hline $\begin{array}{l}\text { Campanella } \\
\text { Serino (2019) }\end{array}$ & and Southern Italy & $\begin{array}{l}\text { Gender, age, education and } \\
\text { experience }\end{array}$ & $\begin{array}{l}\text { Loan application and } \\
\text { approval }\end{array}$ & $\begin{array}{l}\text { Age is a significant factor for both } \\
\text { the application and the approval of } \\
\text { the loan. Education and experience } \\
\text { do not affect the probability of } \\
\text { borrowing or the repayment } \\
\text { probability }\end{array}$ \\
\hline
\end{tabular}

Serino, Papa, Italy Female manager, board of ROE and credit price The presence of women on the
Campanella and (north vs south) directors, organizational model, board positively influences ROE. Mueller (2019) position, size and sector Southern Italy companies are less performing than the rest of the country

\begin{tabular}{|c|c|c|c|}
\hline $\begin{array}{l}\text { Campanella and Southern Italy } \\
\text { Serino (2019) }\end{array}$ & $\begin{array}{l}\text { Gender, age, education and } \\
\text { ethnicity }\end{array}$ & Bank loan & $\begin{array}{l}\text { Loans for male entrepreneurs are } \\
\text { accepted more than for women }\end{array}$ \\
\hline $\begin{array}{l}\text { Coleman and Robb United States } \\
\text { (2009) }\end{array}$ & Size, education and experience & $\begin{array}{l}\text { Financial and equity } \\
\text { investment register }\end{array}$ & $\begin{array}{l}\text { Men are more educated and have } \\
\text { more work experience than } \\
\text { women. Women run smaller } \\
\text { companies }\end{array}$ \\
\hline $\begin{array}{l}\text { Neeley and Van United States } \\
\text { Auxen (2010) }\end{array}$ & $\begin{array}{l}\text { Education, age, agreements } \\
\text { made for external capital, } \\
\text { gender and change in sales }\end{array}$ & Using the bootstrap & $\begin{array}{l}\text { Despite the convenience of the } \\
\text { bootstrap, women use it less than } \\
\text { men }\end{array}$ \\
\hline $\begin{array}{l}\text { Williams and K'nIfe Jamaica } \\
\text { (2012) }\end{array}$ & $\begin{array}{l}\text { Education, years of work } \\
\text { experience, size, years of } \\
\text { activity and organizational } \\
\text { form }\end{array}$ & $\begin{array}{l}\text { Gender and credit } \\
\text { behavior }\end{array}$ & $\begin{array}{l}\text { Men have more years of work } \\
\text { experience and are more educated } \\
\text { than women. The companies run by } \\
\text { men are companies differently } \\
\text { from those of women }\end{array}$ \\
\hline
\end{tabular}

Garwe and Fatoki East London, Port Number of employees, Credit demand and Women apply for fewer loans than (2012) Elizabeth, Queenstown guarantees, company sector, availability men; there were no differences in and King Williams Town membership of associations, the availability of credit (south- Africa) education and age

van Hulten (2012) Western Austria, New Size, age, sector, education, Growth and finance Women are less likely to have South Wales, Victoria, experience, reimbursement and repaid their debt late and to have South Australia and demand applied for funding Tasmania (Australia)

\begin{tabular}{lllll}
\hline $\begin{array}{l}\text { Nellaloge and Locke } \\
\text { (2017) }\end{array}$ & $\begin{array}{l}\text { Bangladesh, Bhutan, Gender and women in Credit constraints } \\
\text { India, Nepal and parliament } \\
\text { Pakistan (South Asia) }\end{array}$ & & $\begin{array}{l}\text { The presence of women in } \\
\text { parliament is negatively related to } \\
\text { credit constraints }\end{array}$ \\
\hline
\end{tabular}

Guercio, Oliveras, Eastern Europe and Age, number of employees, Gender and access to Women pay higher interest rates Vigier and Briozzo Central Asia level of capacity utilization and bank financing than men (2015) percentage of sales

Metu, Nwokoye and Awka (Nigeria) Source of initial capital, source Development $\quad$ of Women lack funding and ask for Kolu (2015) of the interviewee's loan, entrepreneurship support from family and friends number of loans, situations in which the interviewee asked for loans, guarantees and situations in which credits / loans had repayment terms

\begin{tabular}{|c|c|c|c|}
\hline $\begin{array}{l}\text { Adesua- } \\
(2011)\end{array}$ & Lincoln Lagos (Nigeria) & $\begin{array}{l}\text { Gender, age, educational level, Credit access } \\
\text { sector and experience }\end{array}$ & $\begin{array}{l}\text { Women find it difficult to access } \\
\text { credit because they have less work } \\
\text { experience. They are engaged in } \\
\text { low-income activities }\end{array}$ \\
\hline $\begin{array}{l}\text { Mohamed } \\
(2015)\end{array}$ & Elnur Khortoum State (Sudan) & $\begin{array}{l}\text { Complexity of administrative Gender } \\
\text { procedures, lack of project } \\
\text { marketing, profit margin, role } \\
\text { of the financial company, lack } \\
\text { of awareness of investments, } \\
\text { guarantees, experience, } \\
\text { payment period and problems } \\
\text { in obtaining financing }\end{array}$ & $\begin{array}{l}\text { All the features contribute to } \\
\text { hampering access to credit for } \\
\text { women entrepreneurs }\end{array}$ \\
\hline
\end{tabular}




\begin{tabular}{|c|c|c|c|}
\hline $\begin{array}{l}\text { Treichel and Scott } \\
\text { (2006) }\end{array}$ & $\begin{array}{l}\text { Great Lakes and Plains } \\
\text { region }\end{array}$ & $\begin{array}{l}\text { Gender, size of the business, Loan application to a } \\
\text { years of activity, sales growth, bank } \\
\text { shape of the business and sector }\end{array}$ & $\begin{array}{l}\text { Women do not apply for bank loans } \\
\text { because of the variables listed }\end{array}$ \\
\hline $\begin{array}{l}\text { Galli and Rossi } \\
(2017)\end{array}$ & $\begin{array}{l}\text { Finland, the Netherlands, } \\
\text { Italy, Austria, Spain, } \\
\text { France and Germany }\end{array}$ & $\begin{array}{l}\text { Gender, age, sector, country, Request and } \\
\text { property, market share, obtaining of external } \\
\text { concentration of the banking funds } \\
\text { system, size, share capital and } \\
\text { bad debt }\end{array}$ & $\begin{array}{l}\text { Women do not require external } \\
\text { sources and rely on personal } \\
\text { sources. They do not obtain } \\
\text { external sources because they are } \\
\text { considered adverse }\end{array}$ \\
\hline $\begin{array}{l}\text { Usman, Farooq, } \\
\text { Zhang, Makki and } \\
\text { Sun (2019) }\end{array}$ & China & $\begin{array}{l}\text { Board size, independence and Cost of debt } \\
\text { activity, institutional } \\
\text { participation, state-owned } \\
\text { enterprises and members' } \\
\text { ownership shares and risk, } \\
\text { growth, opportunity, short and } \\
\text { long-term debt ratio, } \\
\text { performance and ROE }\end{array}$ & $\begin{array}{l}\text { Women are less risky and are less } \\
\text { accused of debt financing }\end{array}$ \\
\hline Zegarra (2014) & Lima (Perù) & $\begin{array}{l}\text { Experience, marital status, Gender and loan } \\
\text { education, maturity and application } \\
\text { reimbursement }\end{array}$ & $\begin{array}{l}\text { Women, especially when they are } \\
\text { married and have children, are } \\
\text { unlikely to receive their loan } \\
\text { applications }\end{array}$ \\
\hline $\begin{array}{l}\text { Borghans, Lex, } \\
\text { Golsteyn, Heckman } \\
\text { and Meijers (2009) }\end{array}$ & $\begin{array}{l}\text { Comas, San Juan de } \\
\text { Miraflores and Climbate } \\
\text { (Perù) }\end{array}$ & $\begin{array}{l}\text { Sector guarantees } \\
\text { documents required }\end{array}$ & $\begin{array}{l}\text { The waiting period between the } \\
\text { application and the delivery is } \\
\text { about two months }\end{array}$ \\
\hline
\end{tabular}

\section{Conclusions and Limitations}

This article discussed the issue of access to credit for women entrepreneurs and, in particular, some of the main obstacles they encounter when, for example, they request a loan from a bank or any institutional investor.

Among the many problems, four were identified: problems on the demand and supply side, obstacles related to both the characteristics of the company (size, company sector, position, etc.) and those of the entrepreneur (level of education and experience, years of activity, gender, etc.), barriers encountered due to social and cultural traditions and hitches related to the lack of financial resources and, therefore, the support received from family and friends.

A systematic literature was used to search for documents and, from the results obtained, it was found that: women entrepreneurs tend to be discriminated against by banks when applying for a loan because they are considered risk-adverse; In addition, higher interest rates are applied than their counterparts. Female entrepreneurs have been found to operate low-income businesses and their level of education and work experience is lower than that of entrepreneurs. Women are also rejected because they do not have enough financial resources: in fact, when they decide to invest or open their own company, they resort to family members.

Finally, the country's cultural traditions also tend to discriminate against them and not allow them to succeed.

The work has some limitations: only some of the problems that affect women entrepreneurs when they request access to credit have been analyzed. Furthermore, most of the studies were carried out in non-European countries (China, Asia, Peru, Nigeria, etc.). Finally, the same variables are often used in studies, such as: gender, level of education and experience for the entrepreneur and size, position, sector and number of employees for the company.

Therefore, other variables could be added to the model such as, for example, the current ratio (index according to which current assets must be at least double the short-term debt), to verify the level of effective availability of women-led businesses and attest if they really have less financial resources than men. Furthermore, studies could be conducted in Italy and, in particular, in southern Italy, given the shortage. Finally, the various interventions by the State could be analyzed in detail and not only in support of the growth of women's enterprises. All these issues are postponed for future research.

\section{References}

Akehurst, G., Simarro, E., \& Mas-Tur, A. (2012). Women entrepreneurship in small service firms: Motivations, barriers and performance. Service Industries Journal, 32(15), 2489-2505. https://doi.org/10.1080/02642069.2012.677834

Alesina, A. F., Lotti, F., \& Mistrulli, P. E. (2013). Do women pay more for credit? evidence from Italy. Journal of the European Economic Association, 11(SUPPL.1), 45-66. https://doi.org/10.1111/j.1542-4774.2012.01100.x 
Asiedu, E., Kalonda-Kanyama, I., Ndikumana, L., \& Nti-Addae, A. (2013). Access to credit by firms in sub-Saharan Africa: How relevant is gender? American Economic Review, 103(3), 293-297. https://doi.org/10.1257/aer.103.3.293

Aterido, R., Beck, T., \& Iacovone, L. (2013). Access to Finance in Sub-Saharan Africa: Is There a Gender Gap?. World Development, 47, 102-120. https://doi.org/10.1016/j.worlddev.2013.02.013

Baidoo, S. T., Sakyi, D., \& Aidoo, J. B. (2020). Does gender matter in credit denial among small and medium scale enterprises in Ghana? International Journal of Entrepreneurship and Small Business, 39(3), 339-362. https://doi.org/10.1504/IJESB.2020.104980

Beck, T., Behr, P., \& Madestam, A. (2018). Sex and credit: Do gender interactions matter for credit market outcomes? Journal of Banking and Finance, 87, 380-396. https://doi.org/10.1016/j.jbankfin.2017.10.018

Bellucci, A., Borisov, A., \& Zazzaro, A. (2010). Does gender matter in bank-firm relationships? Evidence from small business lending. Journal of Banking and Finance, 34(12), 2968-2984. https://doi.org/10.1016/j.jbankfin.2010.07.008

Blanchflower, D. G., Levine, P. B., \& Zimmerman, D. J. (2003). Discrimination in the small-business credit market. Review of Economics and Statistics, 85(4), 930-943. https://doi.org/10.1162/003465303772815835

Borghans, L., Golsteyn, B. H. H., Heckman, J. J., \& Meijers, H. (2009). Gender differences in risk aversion and ambiguity aversion. Journal of the European Economic Association, 7(2-3), 649-658. https://doi.org/10.1162/JEEA.2009.7.2-3.649

Brush, C. G. (2009). Women Entrepreneurs: A Research Overview (Book Chapter). The Oxford Handbook of Entrepreneurship. https://doi.org/10.1093/oxfordhb/9780199546992.003.0023

Calcagnini, G., Giombini, G., \& Lenti, E. (2015). Gender Differences in Bank Loan Access: An Empirical Analysis. Italian Economic Journal, 1(2), 193-217. https://doi.org/10.1007/s40797-014-0004-1

Campanella, F., \& Serino, L. (2019). Gender and financial constraints: An empirical investigation in Italy. International Journal of Financial Research, 10(2). https://doi.org/10.5430/ijfr.v10n2p109

Cesaroni, F. M., \& Sentuti, A. (2015). Access to bank credit during the economic crisis: A comparison between Italian male and female entrepreneurs. Proceedings of the European Conference on Innovation and Entrepreneurship, ECIE 2015-January, 121-129.

Chapelle, K. (2012). Personal assets, access to credit and gender entrepreneurial disparities: The case of the South African informal sector. Savings and Development, 36(1), 25-69. https://doi.org/10.2307/savideve.36.1.25

Charness, G., \& Gneezy, U. (2012). Strong Evidence for Gender Differences in Risk Taking. Journal of Economic Behavior and Organization, 83(1), 50-58. https://doi.org/10.1016/j.jebo.2011.06.007

Chaudhuri, K., Sasidharan, S., \& Raj, R. S. N. (2020). Gender, small firm ownership, and credit access: some insights from India. Small Business Economics, 54(4), 1165-1181. https://doi.org/10.1007/s11187-018-0124-3

Coleman, S. \& Robb, A. (2012). Financing Women-Owned Firms: A Review Of Recent Literature (Book Chapter). The Oxford Handbook of Entrepreneurial Finance. https://doi.org/10.1093/oxfordhb/9780195391244.013.0024

Coleman, S. (2000). Access to capital and terms of credit: A comparison of men-and women-owned small businesses. Journal of Small Business Management, 38(3), 37-52.

Constantinidis, C., Cornet, A., \& Asandei, S. (2006). Financing of women-owned ventures: The impact of gender and other owner- and firm-related variables. Venture Capital, 8(2), 133-157. https://doi.org/10.1080/13691060600572557

Das, B., \& Xiaofeng, H. (2017). Financing source for women owned SMEs: An evidence from Nepal. 2017 3rd International Conference on Information Management, ICIM 2017 7950364, 144-148. https://doi.org/10.1109/INFOMAN.2017.7950364

De Mel, S., McKenzie, D., \& Woodruff, C. (2009). Are women more credit constrained? Experimental evidence on gender and microenterprise returns. American Economic Journal: Applied Economics, 1(3), 1-32. https://doi.org/10.1257/app.1.3.1

Eckel, C. C., \& Grossman, P. J. (2008). Chapter 113 Men, Women and Risk Aversion: Experimental Evidence. Handbook of Experimental Economics Results, $1(\mathrm{C}), \quad$ 1061-1073. 
https://doi.org/10.1016/S1574-0722(07)00113-8

Eckel, C. C., \& Grossman, P. J. (2008). Forecasting risk attitudes: An experimental study using actual and forecast gamble choices. Journal of Economic Behavior and Organization, 68(1), 1-17. https://doi.org/10.1016/j.jebo.2008.04.006

Galli, E., \& Rossi, S. P. S. (2016). Bank credit access and gender discrimination: Some stylized facts. Contributions to Economics, 214, 111-123. https://doi.org/10.1007/978-3-319-17413-6_8

Galli, E., Mascia, D. V., \& Rossi, S. P. S. (2019). Bank credit constraints for women-led SMEs: Self-restraint or lender bias? European Financial Management. https://doi.org/10.1111/eufm.12255

Garwe, D. K., \& Fatoki, O. (2012). The impact of gender on SME characteristics and access to debt finance in South Africa. Development Southern Africa, 29(3), 448-461. https://doi.org/10.1080/0376835X.2012.706040

Goswami, K., Hazarika, B., \& Handique, K. (2017). Determinants of financial risk attitude among the handloom micro-entrepreneurs in North East India. Asia Pacific Management Review, 22(4), 168-175. https://doi.org/10.1016/j.apmrv.2017.07.013

Graham, J. F., Stendardi, E. J., Myers, J. K., \& Graham, M. J. (2002). Gender differences in investment strategies: An information processing perspective. International Journal of Bank Marketing, 20(1), 17-26. https://doi.org/10.1108/02652320210415953

Guercio, M. B., Oliveras, G., Vigier, H. P., \& Briozzo, A. E. (2015). External financing from a gender perspective [Financiamiento externo desde una perspectiva de género]. Revista Venezolana de Gerencia, 20(71), 440-454. https://doi.org/10.31876/revista.v20i71.20196

Jurajda, Ц̌., \& Janhuba, R. (2018). Gender in banking and mortgage behavior. Applied Economics Letters, 25(20), 1432-1435. https://doi.org/10.1080/13504851.2018.1430304

Le, L. H., \& Stefańczyk, J. K. (2018). Gender discrimination in access to credit: Are women-led SMEs rejected more than men-led? Gender, Technology and Development, 22(2), 145-163. https://doi.org/10.1080/09718524.2018.1506973

Lee, J. (2013). Women's access to credit: Asian women's double burden. Asian Women, 29(2), 49-81.

Lindvert, M., Patel, P. C., \& Wincent, J. (2017). Struggling with social capital: Pakistani women micro entrepreneurs' challenges in acquiring resources. Entrepreneurship and Regional Development, 29(7-8), 759-790. https://doi.org/10.1080/08985626.2017.1349190

Madill, J. J., Riding, A. L., \& Haines, G. H. (2006). Women Entrepreneurs: Debt Financing and Banking Relationships. Journal of Small Business and Entrepreneurship, 19(2), 121-142. https://doi.org/10.1080/08276331.2006.10593363

Marlow, S., \& Swail, J. (2014). Gender, risk and finance: Why can't a woman be more like a man? $\begin{array}{llll}\text { Entrepreneurship and Regional Development, } & \text { 26(1-2), }\end{array}$ https://doi.org/10.1080/08985626.2013.860484

Marlow, S., Hicks, S., \& Treanor, L. (2019). Gendering entrepreneurial behaviour (Book Chapter). Entrepreneurial Behaviour: Individual, Contextual and Microfoundational Perspectives, 39-60. https://doi.org/10.1007/978-3-030-04402-2_3

Mijid, N. (2014). Why are female small business owners in the United States less likely to apply for bank loans than their male counterparts? Journal of Small Business and Entrepreneurship, 27(2), 229-249. https://doi.org/10.1080/08276331.2015.1012937

Mijid, N., \& Bernasek, A. (2013). Gender and the credit rationing of small businesses. Social Science Journal 50(1), 55-65. https://doi.org/10.1016/j.soscij.2012.09.002

Moro, A., Wisniewski, T. P., \& Mantovani, G. M. (2017). Does a manager's gender matter when accessing credit? Evidence from European data. Journal of Banking and Finance, 80, 119-134. https://doi.org/10.1016/j.jbankfin.2017.04.009

Morsy, H. (2020). Access to finance - Mind the gender gap. Quarterly Review of Economics and Finance. https://doi.org/10.1016/j.qref.2020.02.005

Muravyev, A., Talavera, O., \& Schäfer, D. (2009). Entrepreneurs' gender and financial constraints: Evidence from international data. Journal of Comparative Economics, 37(2), 270-286. https://doi.org/10.1016/j.jce.2008.12.001 
Neeley, L., \& Van Auken, H. (2010). Differences between female and male entrepreneurs' use of bootstrap $\begin{array}{llll}\text { financing. Journal of Developmental } & \text { Entrepreneurship }\end{array}$ https://doi.org/10.1142/S1084946710001439

Nwosu, E. O., \& Orji, A. (2016). Access to formal credit and enterprise performance in Nigeria: A gender perspective. Argumenta Oeconomica, 36(1), 191-224. https://doi.org/10.15611/aoe.2016.1.08

Ongena, S., \& Popov, A. (2016). Gender Bias and Credit Access. Journal of Money, Credit and Banking, 48(8), 1691-1724. https://doi.org/10.1111/jmcb.12361

Presbitero, A. F., Rabellotti, R., \& Piras, C. (2014). Barking up the Wrong Tree? Measuring Gender Gaps in Firm's Access to Finance. Journal of Development Studies, 50(10), 1430-1444. https://doi.org/10.1080/00220388.2014.940914

Read, D. C., \& Leland, S. M. (2017). Toward Understanding Another Gender Gap: How Women in Economic Development Perceive Access to Capital. Journal of Women, Politics and Policy, 38(4), 481-497. https://doi.org/10.1080/1554477X.2016.1268873

Sackey, F. G., \& Amponsah, P. N. (2018). Gender discrimination in commercial banks' credit markets in Ghana: A decomposition and counterfactual analysis. African Journal of Business and Economic Research, 13(2), 121-140. https://doi.org/10.31920/1750-4562/2018/v13n2a6

Serino, L., Papa, A., Campanella, F., \& Mueller, J. (2019). Credit access and performance of Italian firms: How relevant is gender? International Journal of Managerial and Financial Accounting, 11(3-4), 269-289. https://doi.org/10.1504/IJMFA.2019.104132

Shoma, C. D. (2019). Financing female entrepreneurs in cottage, micro, small, and medium enterprises: Evidence from the financial sector in Bangladesh 2010-2018. Asia and the Pacific Policy Studies, 6(3), 397-416. https://doi.org/10.1002/app5.286

Shoma, C. D. (2019). Gender is a human rights issue: The case of women's entrepreneurship development in the Small and Medium Enterprise sector of Bangladesh. Journal of International Women's Studies, 20(7), 13-34.

Stefani, M. L., \& Vacca, V. (2015). Small firms' credit access in the Euro area: Does gender matter? CESifo Economic Studies, 61(1), 165-201. https://doi.org/10.1093/cesifo/ifu031

Treichel, M. Z., \& Scott, J. (2006). Women-owned businesses and access to bank credit: Evidence from three surveys since 1987. Venture Capital, 8(1), 51-67. https://doi.org/10.1080/13691060500453726

Usman, M., Farooq, M. U., Zhang, J., Makki, M. A. M., \& Sun, J. (2019). She-E-Os and the Cost of Debt: Do Female CEOs Pay Less for Credit?. B. E. Journal of Economic Analysis and Policy, 19(1), 20180177.

van Hulten, A. (2012). Women's access to SME finance in Australia. International Journal of Gender and Entrepreneurship, 4(3), 266-288. https://doi.org/10.1108/17566261211264154

Verheul, I., \& Thurik, R. (2001). Start-Up Capital: “Does Gender Matter?”. Small Business Economics, 16(4), 329-346. https://doi.org/10.1023/A:1011178629240

Welsh, D. H., Kim, G., Memili, E., \& Kaciak, E. (2014). The influence of family moral support and personal problems on firm performance: The case of Korean female entrepreneurs. Journal of Developmental Entrepreneurship, 19(3), 1450018. https://doi.org/10.1142/S1084946714500186

Williams, D. A., \& K'nIfe, A. K. (2012). Correlates of gender and credit behavior in small firms: Evidence from a small, developing economy. Entrepreneurial Executive, 17, 69-85.

Zegarra, L. F. (2013). Women and credit in peru during the guano era. Was there gender discrimination in the mortgage credit market of peru? Revista de Historia Economica - Journal of Iberian and Latin American Economic History, 32(1), 151-185. https://doi.org/10.1017/S0212610914000020

\section{Copyrights}

Copyright for this article is retained by the author(s), with first publication rights granted to the journal.

This is an open-access article distributed under the terms and conditions of the Creative Commons Attribution license (http://creativecommons.org/licenses/by/4.0/). 